\title{
ZABUDOWANIA PARAFII ŚW. STANISŁAWA BISKUPA W MODLIBORZYCACH W ŚWIETLE WIZYTACJI PREPOZYTA ANTONIEGO FRANCISZKA DUNIN-KOZICKIEGO Z 1781 R.
}

Akta wizytacyjne parafii z XVIII w. stanowią znakomite źródło służące poznaniu dziejów organizacji kościelnej na danym terenie, w tym jej stanu materialnego ${ }^{1}$. Wizytacje $\mathrm{z}$ tego okresu, w odróżnieniu od wizytacji XVI i częściowo także XVII w., charakteryzowały się dużym stopniem szczegółowości ${ }^{2}$. Niejednokrotnie stanowią nawet jedyne źródło informacji, zwłaszcza tam gdzie starsze przekazy pisane nie zachowały się s $^{3}$ Stąd akta wizytacyjne stały się polem szczególnego zainteresowania badaczy i są w ostatnich latach z sukcesami wydawane ${ }^{4}$.

* Dominik Szulc - mgr historii, doktorant w Instytucie Historii UMCS w Lublinie.

${ }^{1} \mathrm{~S}$. Litak, Akta wizytacyjne parafii z XVI-XVIII wieku jako źródło historyczne, „Zeszyty Naukowe KUL", 5 (1962) nr 3, s. 45-46.

${ }^{2}$ Tamże, s. 46; zob. też S. Litak, Wstęp, w: Akta wizytacji generalnej diecezji inflanckiej i kurlandzkiej czyli piltyńskiej z 1761 r., Toruń 1998, wyd. S. Litak, s. XIV.

${ }^{3}$ Por. E. Wiśniowski, Rozwój sieci parafialnej w prepozyturze wiślickiej w średniowieczu. Studium geograficzno-historyczne, Warszawa 1965, opis nr 68, s. 154.

${ }^{4}$ Zob. m.in. Visitatio Diocesis Samogitiae (A. D. 1579). Ţemaičiř vyskupijos vizitacija (1579), opr. J. Tumelis, L. Jovaiš, Vilnius 1998; Akta wizytacji generalnej diecezji inflanckiej i kurlandzkiej; Vyskupo Ignoto Jokübo Masalskio kauno dekanato vizitacija 1782 m., opr. i wyd. V. Jogëla, Vilnius 2001; A. Biedrzycka, Kościót katedralny w Kamieńcu Podolskim w świetle wizytacji z 1741 roku, „Rocznik Biblioteki Naukowej PAU i PAN w Krakowie”, XLVIII (2002), s. 9-80; Wizytacja biskupstwa sambijskiego z 1569 roku, wyd. J. Wijaczka, Torun 2002; Protokoły wizytacyjne dekanatu bytomskiego z lat 1792-1793, wyd. J. Pater, Poznań-Wrocław 2003; Wizytacje generalne parafii unickich w województwie kijowskim i bracławskim po 1782 roku, opr. i wyd. M. Radwan, Lublin 2004; Wizytacja biskupstwa sambijskiego z 1570 roku, wyd. J. Wijaczka, Torun 2005; por. m.in. W. Kriegseisen, ,, Akta wizytacji wizytacji generalnej diecezji inflanckiej i kurlandzkiej czyli piltyńskiej z 1761 roku”., wyd. S. Litak (recenzja), „Kwartalnik Historyczny”, CVI (1999) nr 3, s. 105-107; R. Biskup, „,Wizytacja biskupstwa sambijskiego z 1569 roku”, wyd. J. Wijaczka (recenzja), ,Zapiski Historyczne”, LXVIII (2003), z. 2-3, s. 256-258; Tenże, ,Wizytacja biskupstwa sambijskiego z 1570 roku”, wyd. J. Wijaczka, „Zapiski Historyczne”, LXXII (2007), z. 4, s. 169-172. Co prawda wizytacja kościoła w Modliborzycach z 1781 r. nie została dotychczas wydana, jednak stała się już przedmiotem 
Stały się one także przedmiotem licznych analiz, na ich podstawie powstają różne studia ${ }^{5}$.

Istotne miejsce zajmowały w nich informacje o zewnętrznym i wewnętrznym wyglądzie zarówno kościołów, jak i wszystkich innych zabudowań parafialnych, w tym mieszkalnych i gospodarczych. Wizytacje przeprowadzali duchowni różnych stopni. Mogli to być sami biskupi, lecz zwykle delegowali do tego wizytatorów spośród podległego sobie duchowieństwa, najczęściej archidiakonów, dziekanów i kanoników. Zgodnie z klasyfikacją Stanisława Litaka, tego typu wizytacje określa się mianem generalnych, przy czym te, które odnosiły się do ogółu spraw materialno-instytucjonalnych, nazywa się zewnętrznymi, dla odróżnienia od wewnętrznych, dotyczących wyłącznie spraw moralno-obyczajowych kleru' Wizytację, która mnie interesuje, należy nazwać materialno-instytucjonalną.

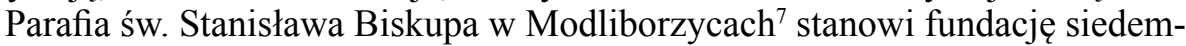
nastowieczną. Pierwotny kościół, niebędący jeszcze parafialnym i wzniesiony zapewne $\mathrm{z}$ drewna ${ }^{8}$, miano zbudować już w 1629 r., a więc na dwa lata przed wy-

bliższego zainteresowania badaczy (patrz m.in. Z. Góralski, Szpitale na Lubelszczyźnie w okresie przedrozbiorowym (cz. II), Lublin 1999, s. 86-87; J. Bazylak, Zarys historii parafii Modliborzyce (cz. 1) , „Janowskie korzenie”, nr 6 (2006) s. 24).

${ }^{5}$ Zob. m.in. J. Szymański, Z dziejów wizytacji archidiakońskich. Czynności i dokumenty wizytacyjne archidiakonów wojnickich, „Roczniki Humanistyczne”, VIII (1959) z. 2, s. 273-293; S. O1czak, Akta wizytacyjne jako podstawa źródłowa do badań nad siecia szkół parafialnych (na przykładzie archidiakonatu średzkiego), „Archiwa, Biblioteki i Muzea Kościelne”, 24 (1972), s. 293-308; V. Kamuntavičienë, Szpitale i szkoły parafialne diecezji wileńskiej i żmudzkiej $w$ drugiej połowie XVII wieku wedlug danych akt wizytacyjnych kościoła katolickiego, „Kwartalnik Historyczny”, CX (2003) $\mathrm{nr}$ 2, s. 51-72; por. W. Kwiatkowska, Stan registratur parafialnych w ewangelickiej diecezji (superintendenturze) toruńskiej w świetle protokołów wizytacyjnych z lat 1840-1916, „Zapiski Historyczne", LXXI (2003) z. 2-3, s. 135-148; J. Wiśniewski, Fabrica ecclesiae na terenie oficjalatu pomezańskiego w świetle wizytacji biskupich XVII-XVIII wieku (cz. I), „Archiwista Polski”, 2 (2007) s. 47-56; cz. II, „Archiwista Polski”, 4 (2007) s. 23-44. Obszerny wykaz prac charakteryzujących wizytacje i oceniających ich przydatność do różnego typu badań podaje M. Surdacki, Wizytacja apostolska z lat 1737-1749 jako źródło do badań nad podrzutkami w Rzymie, „Kwartalnik Historyczny", CIX (2002) nr 4, s. 25-26, przyp. 3.

${ }^{6}$ Litak, Akta wizytacyjne parafii, s. 44; Tenże, Wstęp, w: Akta wizytacji generalnej diecezji inflanckiej i kurlandzkiej, s. XI-XXIII; A. Hamryszczak, Materiały do badań genealogicznych w zasobach Instytutu Archiwów, Bibliotek i Muzeów Kościelnych KUL w Lublinie, „Rocznik Lubelskiego Towarzystwa Genealogicznego", 1 (2009), s. 116-118.

${ }^{7}$ Jak wynika z tekstu wizytacji kościoła z 1689 r. musiał on przejściowo nosić także wezwanie podwójne - św. Stanisława Biskupa i św. Marcina (Archiwum Kurii Metropolitalnej w Krakowie (dalej: AKMKr.), AV Cap. 66, Visitatio externa archidiaconatus Zawichostensis A. D. 1689 in mense Novembre et Decembre Expedia, in qua iura ecclesiarum, proventus parochorum una cum descriptionibus ecclesiarum et aedificiorum, noviter et ante existentium, connotata demonastrantur. Decanatus: Urzędowiensis, Zawichostensis et Opatoviensis, s. 13).

${ }^{8}$ Por. Biblioteka Polskiej Akademii Nauk i Polskiej Akademii Umiejętności w Krakowie (dalej: BPAN-PAUKr.), rkps. 2375 (J. A. Wadowski, Kościoły w Lublinie i diecezji krakowskiej, t. I), s. 329. 
daniem przez Zygmunta III pierwszego przywileju lokacyjnego dla Modliborzyc ${ }^{9}$, lub też $\mathrm{w} 1634 \mathrm{r}^{10}$ Akt fundacyjny tego najstarszego kościoła przechowywano rzekomo w bibliotece kościelnej w Modliborzycach jeszcze w 1781 r., co jest jednak wątpliwe ${ }^{11}$, zaś jego wystawcą miał być Stanisław Wieteski (Wioteski), herbu Rola, stolnik bełski, właściciel Modliborzyc i Bychawy ${ }^{12}$. Wieteski pier-

${ }^{9}$ J. Łosowski, Kancelarie miast szlacheckich województwa lubelskiego od XV do XVIII wieku, Lublin 1997, s. 100.

${ }^{10}$ U. Bzdyra, Dzieje Modliborzyc. Kalendarium, „Wieści Gminne”, 10 (2008) s. 23 (podaje nawet lokalizację świątyni - modliborzycki rynek, który nie odpowiada obecnej lokalizacji kościoła. Niestety nie przywołuje żadnej podstawy tego twierdzenia).

${ }^{11}$ Archiwum Archidiecezjalne Lubelskie (dalej: AAL), Rep 60, A 105, Akta Wizyty Generalney $w$ trzech Dekanatach Chodelskim, Urzędowskim y Kazimierskim z woli y rozkazu Jaśnie Oświeconego Imci X. Kajetana Ignacego Soltyka Biskupa Krakowskiego Xiązęcia Siewierskiego przez X. Antoniego Franciszka Dunina Kozickiego Kolegiaty Pileckiej Dziekana od dnia 15 maja Roku Pańskiego 1781 poczęty, a w Roku 1782 dniach ostatnich miesiaca stycznia odprawioney y dokończoney spisane, s. 564. O dokumencie tym oraz istnieniu kościoła filialnego w Modliborzycach od $1629 \mathrm{r}$. nie wspominają wizytacje XVII-wieczne. Możliwe więc, że do tekstu z 1781 r. wkradł się błąd, tym bardziej, że Modliborzyce jeszcze wówczas nie istniały. Dopiero bowiem w przywileju Zygmunta III z 1631 r. czytamy o dokonanej przez króla zamianie wsi dziedzicznej Słupie na miasto Modliborzyce (Archiwum Główne Akt Dawnych w Warszawie, Komisja Rządowa Spraw Wewnętrznych i Policji (dalej: AGAD, KRSW), sygn. 3194, s. 193). Nic w tej kwestii nie może zmienić wpis do jednej z lubelskich ksiąg grodzkich z 1691 r. informujący o Żydzie Baruchu, który miał od ok. 70 lat prowadzić w Modliborzycach działalność propinacyjną w dzierżawionej przez siebie karczmie i browarze (Materiaty źródlowe do dziejów Żydów w księgach grodzkich lubelskich z doby panowania Michała Korybuta Wiśniowieckiego i Jana III Sobieskiego 1669-1697, opr. H. Gmiterek, Lublin 2003, nr 1546, s. 254). Oczywiście mógł ją rozpocząć ok. 1621 r. w Słupiu, jednak jest to raczej błąd, gdyż Żyd ten musiałby w końcu XVII w. być już w niezwykle podeszłym wieku.

${ }^{12}$ Niewiele wiadomo na jego temat. Był synem Jana (Archiwum Państwowe w Kielcach/Oddział w Sandomierzu (dalej: APK/OS), sygn. 949/189, Hipoteka $w$ Janowie, nr 4, wypis z księgi grodzkiej lubelskiej z 1802 r.), żyjącego jeszcze w 1627 r. prawdopodobnego oficjalisty u Zamoyskich (por. AGAD, Archiwum Zamoyskich (dalej: AGAD, AZ), sygn. 749, s. 43-45). Z kolei jego matką mogła być żona Jana Zofia, żyjąca jeszcze w 1629 r. (por. tamże, sygn. 986, s. 1). Herb S. Wieteskiego - Rola, stał się później godłem miasta Modliborzyce (M. Gumowski, Pieczęcie i herby miejscowości województwa lubelskiego, Lublin 1959, s. 66; por. AGAD, AZ, sygn. 712, s. 140 - odcisk pieczęci z herbem Rola i literami S W na papierze). Późniejszy fundator kościoła w Modliborzycach był pierwotnie oficjalistą, a następnie podskarbim Zamoyskich. Stąd licznie jeszcze zachowana korespondencja S. Wieteskiego z ordynatami i nie tylko z lat 1609-1639 (zob. AGAD, AZ, sygn. 436, s. 8; sygn. 705, s. 43-44; sygn. 712, s. 139-141; sygn. 716, s. 38; sygn. 742, s. 101; sygn. 749, s. 46-69; sygn. 919, brak paginacji; sygn. 987, brak paginacji). Na urząd stolnika w Bełzie nominowany został 7 listopada 1626 r. (Urzędnicy województwa betskiego i ziemi chetmskiej XIVXVIII wieku. Spisy, opr. H. Gmiterek i R. Szczygieł, Kórnik 1992, nr 340, s. 66). W 1649 r. wystawił własny poczet pospolitego ruszenia dla chorągwi generalnej województwa lubelskiego (zob. J. Kus, Popis pospolitego ruszenia szlachty województwa lubelskiego z 1649 roku, „Region Lubelski”, 6-8 (1994-1996) s. 137). Stolnikiem bełzkim był jeszcze w 1650, zaś w 1657 r. stolnikiem tym był już Jan Wybranowski (Urzędnicy województwa betskiego i ziemi chetmskiej XIV-XVIII wieku, $\mathrm{nr} 340$ i 342, s. 66). Zdaniem Henryka Gmiterka zginął w wyniku wojen kozackich niedługo po 1650 r. (H. Gmiterek, Dzieje miasta w XVII-XVIII wieku, w: Dzieje Bychawy, red. R. Szczygieł, Bychawa-Lublin 1994, s. 57). Jedna z córek Wieteskiego została później żoną skarbnika lubelskiego Tomasza 
wotnie zamierzał podobno ufundować w Modliborzycach klasztor kanoników regularnych ${ }^{13}$, ale z zamiaru tego ostatecznie wycofał się ${ }^{14}$. Cyprian Walewski, ks. Marek Zahajkiewicz, Wit Szymanek, Urszula Bzdyra, ks. Józef Bazylak i ks. Józef Brzozowski uznali, iż w latach późniejszych nastąpiło przeniesienie parafii z pobliskiej Słupii do Modliborzyc ${ }^{15}$, co datowali na 1664 r., opierając się na wizytacji z 1748 r. ${ }^{16}$ Pogląd ten należy jednak zweryfikować. Znacznie wcześniejsza wizytacja kościoła modliborzyckiego z $1682 \mathrm{r}$. wspomina bowiem powołanie proboszcza dla świątyni w Modliborzycach już 12 stycznia 1654 r. ${ }^{17}$, chociaż kolejna

Inocentego Zaporskiego (tamże). Blisko spokrewniony musiał być z nim ponadto Jan Michał Wieteski, rzekomo herbu Księżyc, dworzanin królewski, a w latach 1669-1671 podczaszy w Trembowli (Urzędnicy województwa ruskiego XIV-XVIII. Spisy, opr. K. Przyboś, Wrocław-Warszawa 1987, nr 581, s. 89/90). Dotował on świątynię modliborzycką w 1654 r. (AKMKr., AV Cap. 12, s. 122). Właścicielem Modliborzyc był już w 1669 r. (Materiały źródłowe do dziejów Żydów w księgach grodzkich lubelskich z doby panowania Władysława IV i Jana Kazimierza Wazów 1633-1669, opr. H. Gmiterek, Lublin 2006, nr 1177, s. 196). Jego żoną była Helena Wieteska, posesorka Bychawy, z którą od ok. 1679 r. żył w separacji (Materiały źródłowe do dziejów Żydów w księgach grodzkich lubelskich z doby panowania Michała Korybuta Wiśniowieckiego i Jana III Sobieskiego 1669-1697, opr. H. Gmiterek, Lublin 2003, nr 646, s. 115). W 1681 r. dziedzicem modliborzyckim był już Stanisław Golecki (tamże, nr 804, s. 139). Ponadto znamy niejakiego Wioteskiego, rotmistrza województwa lubelskiego, którego chorągiew poczyniła liczne szkody w Zaklikowie w $1671 \mathrm{r}$. (tamże, nr 154, s. 39).

Adam Boniecki i Teodor Żychliński nie wspominają o S. Wieteskim w swoich herbarzach, natomiast Kasper Niesiecki pisze o nim dość lakonicznie, nazywając go mężem wojennym, i hojnym (K. Niesiecki, Herbarz Polski, t. IX, Lipsk 1842, s. 327). Być może żył on jeszcze w 1661 r. (patrz przyp. 24 niniejszej pracy). Wraz z rodziną miał być pochowany w kryptach kościoła modliborzyckiego (B. Chlebowski, Modliborzyce, w: Stownik geograficzny Królestwa Polskiego i innych krajów słowiańskich, t. VI, Warszawa 1885, red. F. Sulimierski, B. Chlebowski i W. Walewski, s. 566).

Wlatach 1636-1642 S. Wieteski toczył spórz Janem Wierzbickim, właścicielem Bychawy, o zwrot pożyczonych mu poważnych sum. Prawdopodobnie miasto zostało wyrokiem przysądzone Wieteskiemu, skoro już w 1637 r. występował jako jego pan dziedziczny. Nowy właściciel wyjednał u Władysława IV przywilej na jarmarki dla Bychawy (zob. H. Gmiterek, Dzieje miasta, w: Dzieje Bychawy, s. 56-57).

${ }^{13}$ Klasztor taki istniał już wówczas w nieodległym Kraśniku.

${ }^{14}$ Chlebowski, Modliborzyce, w: Stownik geograficzny, s. 566.

${ }^{15}$ Por. BPAN-PAUKr., rkps. 2375, s. 329.

${ }^{16}$ Tamże, rkps. 757 (C. Walewski, Opis historyczny diecezji krakowskiej z XIX w., bez daty powstania), brak paginacji; M. Zahajkiewicz, Diecezja lubelska. Informator historyczny $i$ administracyjny, Lublin 1985, s. 194; W. Szymanek, Z dziejów powiatu janowskiego i kraśnickiego w latach 1474-1975, Kraśnik 2003, s. 280; U. Bzdyra, Historia parafii i kościoła w Modliborzycach, „Wieści Gminne”, nr 2 (2006) s. 18; ks. J. Bazylak, Zarys historii parafii Modliborzyce (cz. 1), ,Janowskie korzenie", nr 6 (2006) s. 17, przyp. 12; ks. J. Brzozowski, Kościół parafialny w Stupiu ciąg dalszy, „Wieści Gminne”, nr 13 (2008) s. 30.

${ }^{17}$ AKMKr., AV Cap. 12, Acta visitationis decanatum Zawichostensis, Urzędoviensis et Opatovensis ad archidiaconatum Zawichostensem pertinentium in Anno Domini 1682 peractae, s. 121. W 1781 r. w kościele wciąż jeszcze przechowywano akt erekcyjny świątyni, właśnie z 1654 r. (AAL, Rep 60, A 105, s. 569). W tym samym roku S. Wieteski ufundował w Modliborzycach szpital przykościelny (Archiwum Państwowe w Kielcach/Oddział w Sandomierzu, sygn. 949/189, nr 4). 
wizytacja z 1689 r. podaje inną, zapewne błędną, datę 12 stycznia 1657 r. ${ }^{18} \mathrm{Zda}-$ niem ks. Leona Kuśmierczyka do budowy murowanego kościoła w Modliborzycach przystąpiono w $1643 \mathrm{r} .{ }^{19}$ Być może związane było to $\mathrm{z}$ wydaniem w $1642 \mathrm{r}$. przez S. Wieteskiego dokumentu lokacyjnego dla miasta i zezwoleniem na wyrąb w lasach na potrzeby budowlane ${ }^{20}$. Lokacja i rozwój przestrzenny miasta spełniałyby więc tu rolę czynników sprawczych ${ }^{21}$. Akcja ta byłaby ułatwiona także dzięki temu, iż Wieteski był właścicielem Słupii - dotychczasowej siedziby ośrodka parafialnego, jeszcze przynajmniej w $1637 \mathrm{r}^{22}$ Ponadto tekst wizytacji z $1682 \mathrm{r}$. sugeruje obecność w Modliborzycach wikarego, będącego jednocześnie altarystą, już w $1646 \mathrm{r}^{23}$ Tak wczesne istnienie altarii modliborzyckiej może wskazywać na chęć rychłego powołania parafii ${ }^{24}$. Znajdująca się w kościele modliborzyckim barokowa tablica kamienna z ok. połowy XVIII w. informuje o wzniesieniu świątyni przez Wieteskiego w $1661 \mathrm{r}^{25}$, co zapewne stanowi datę zakończenia jej budowy. W prezbiterium znajduje się ponadto późnorenesansowa dekoracja stiukowa w tzw. typie lubelsko-kaliskim z ok. lat 1664-1668. Zawiera ona przedstawienia m.in. herbu Rola i liter fundatora Wieteskiego - S Z M W S B (Stanisław z Modliborzyc Wieteski stolnik bełzki) ${ }^{26}$. Konsekracji kościoła dokonał 7 czerwca 1668 r. sufragan krakowski Mikołaj Oborski27 (późniejszy administrator diecezji lwowskiej $)^{28}$, co tłumaczyć może brak informacji o tym wydarzeniu w księdze czynności pontyfikalnych biskupa krakowskiego Andrzeja Trzebickiego ${ }^{29}$.

${ }^{18}$ AKMKr, AV Cap. 66, s. 14.

${ }^{19}$ L. Kuśmierczyk, Rozwój zaludnienia parafii Stupie-Modliborzyce, „Janowskie korzenie”, 10 (2008) s. 24. Por. J. Bazylak, Zarys historii parafii Modliborzyce (cz. 1), „Janowskie korzenie”, 6 (2006) s. 23.

${ }^{20} \mathrm{~J}$. Łosowski, Kancelarie miast szlacheckich województwa lubelskiego, s. 100. Przywilej ten był w posiadaniu miasta jeszcze w 1865 r. (AGAD, KRSW, sygn. 3817, brak paginacji).

${ }^{21}$ Por. P. Szafran, Rozwój średniowiecznej sieci parafialnej w Lubelskiem, Lublin 1958, s. $97-$ 98.

${ }^{22}$ Zob. AGAD, AZ, sygn. 749, s. 57.

${ }^{23}$ AKMKr., AV Cap. 66, s. 14.

${ }^{24}$ Por. J. Szymański, Altaria, w: Encyklopedia katolicka, t. I, red. F. Gryglewicz, Lublin 1985, s. 387.

${ }^{25}$ Katalog zabytków sztuki w Polsce, t. VIII, pod red. R. Brykowskiego i Z. Winiarz, z. 7, przyg. I. Galicka i E. Rowińska, Warszawa 1961, s. 11. J. A. Wadowski uważał, że budowę kościoła ukończono w 1664 r. (zob. BPAN-PAUKr., rkps. 2375, s. 330).

${ }^{26}$ Katalog zabytków sztuki w Polsce, t. VIII, z. 7, s. 11.

${ }^{27}$ AAL, Rep 60, A 105, s. 556. Ponownej konsekracji kościoła, po jego gruntownym remoncie dokonał 11 września 1884 r. biskup lubelski Kazimierz Wronowski (Chlebowski, Modliborzyce, w: Stownik geograficzny, t. VI, s. 566).

${ }^{28}$ Oborski uchodził za niezwykle pracowitego. Znany był z corocznych objazdów wizytacyjnych diecezji krakowskiej, niekiedy odbywanych w trudnych warunkach. W ich trakcie poświęcił 193 kościoły, 1388 stałych ołtarzy, 342 dzwony, 10 kaplic i 47 cmentarzy (J. Bieniarzówna, Oborski Mikołaj h. Pierzchała vel Roch, w: Polski Stownik Biograficzny (dalej: PSB), t. XXIII, WrocławWarszawa 1978, s. 449).

${ }^{29}$ Por. AKMKr, AEp. 62, Acta actorum episcopalium R.. D. Andreae Trzebicki, episcopi Cracoviensis et ducis Severiae ab anno 1667 ad annum 1669 inclusive. Volumen IV, s. 7-9 (indeks czynności za 1668 r.) i nn. 
Znane od 1682 r. wizytacje obejmujące kościół w Modliborzycach opisywały nie tylko jego wygląd i wyposażenie, ale także stan innych zabudowań będących własnością parafii, jak chociażby szkoły parafialnej, szpitala czy rezydencji plebana. Uzupełnieniem tych wiadomości są regularnie już występujące w protokołach powizytacyjnych z XVII i XVIII w. tzw. dekrety reformacyjne.

Cytowane poniżej opisy zabudowań parafii św. Stanisława Biskupa w Modliborzycach pochodzą z protokołu powizytacyjnego dwóch dekanatów archidiakonatu lubelskiego: chodelskiego i kazimierskiego oraz jednego $\mathrm{z}$ dekanatów archidiakonatu zawichojskiego, czyli urzędowskiego, w granicach którego leżały Modliborzyce. Wizytację tę przeprowadził w latach 1781-1782 ks. Antoni Franciszek Dunin-Kozicki, na polecenie biskupa krakowskiego Kajetana Ignacego Sołtyka. Ks. Kozicki był wówczas plebanem w Mrzygłodzie oraz prepozytem w Szańcu, nieco później został natomiast prepozytem, oficjałem okręgowym i dziekanem kapituły kolegiackiej w Pilicy Nowej ${ }^{30}$. Wizytacji kościoła modliborzyckiego dokonał on zapewne w końcu listopada 1781 r., skoro zakończył ją 30 dnia tego miesiąca ${ }^{31}$. W samym protokole wizytacje nie zostały jednak ułożone zgodnie z chronologią ich odbywania. Była to przy tym prawdopodobnie ostatnia lub jedna $\mathrm{z}$ ostatnich wizytacji parafii w Modliborzycach przeprowadzonych na polecenie biskupa krakowskiego, gdyż w 1790 r. miasto na zawsze oderwano się od diecezji krakowskiej, włączono je początkowo w skład diecezji chełmskiej, następnie kieleckiej, a od 1818 r. diecezji lubelskiej².

Oryginalny protokół powizytacyjny przechowywany jest obecnie w Archiwum Archidiecezjalnym Lubelskim pod sygnaturą Rep 60 A 105. Spisany został jednym, wyraźnym duktem pisma na 1032 papierowych stronach wymiarów $33 \mathrm{x}$ $20 \mathrm{~cm}$. Informacje o kościołach dekanatu urzędowskiego znajdują się na stronach od 382 do 689, przy czym przebieg wizytacji kościoła modliborzyckiego i płynące z niego wnioski spisano na stronach 556-572.

Podstawą wydania niniejszego tekstu jest mikrofilm protokołu wytworzony w 1962 r. i przechowywany obecnie w Międzywydziałowym Instytucie Archiwów, Bibliotek i Muzeów Kościelnych KUL w Lublinie pod sygnaturą 336. Poniższa kopia wydawnicza, opracowana została według zasad ustalonych w in-

${ }^{30}$ Bolesław Kumor uważał, że Kozicki rezydował w Pilicy od 1783 do 1791 r. (B. Kumor, Dzieje diecezji krakowskiej do roku 1795, t. 3, Kraków 2000, s. 389). Tymczasem Jan Szczepaniak podał ostatnio, iż w rzeczywistości miało to miejsce w latach 1784-1794, natomiast karierę rozpoczynał Kozicki we wspomnianym Mrzygłodzie, gdzie plebanem był w latach 1765-1784 (Spis prepozytów i plebanów diecezji krakowskiej (XVIII w.), opr. J. Szczepaniak, Kraków 2008, s. 241, 249-250).

${ }^{31} \mathrm{~W}$ tamtym czasie proboszczem w Modliborzycach był ks. Maciej Kiślewicz, który pełnił tę funkcję od 1775 do 1784 r. Urodził się w 1707 r. Święcenia otrzymał 24 lutego 1733 r. i został klerykiem w Przemyślu. Proboszczem modliborzyckim został dzięki protekcji właściciela Modliborzyc Andrzeja Nahoreckiego (AAL, Rep 60, A 105, s. 566; por. Spis prepozytów i plebanów diecezji krakowskiej, s. 362, gdzie występuje jako Marcin Kizlewicz vel Kiślewicz). Jego krótką notę biograficzną opracował niedawno Józef Bazylak, Zarys historii parafii Modliborzyce (dokończenie), „, Janowskie korzenie", nr 7 (2006) s. 5.

${ }^{32}$ M. Zahajkiewicz, Dzieje Archidiecezji Lubelskiej (1805-2005), Lublin 2005, s. 35-36 i 39-41. 
strukcji wydawniczej dla rękopisów z tego okresu autorstwa Kazimierza Lepszego $^{33}$. Zgodnie z nią, dużą część tekstu oryginalnego zmodernizowano dla ułatwienia czytania i zrozumienia źródła. Przede wszystkim niektóre litery łacińskie transkrybowano do ich wartości fonetycznej np. $y$ zamieniono na $i$. Oryginalne brzmienie zachowały jednak wyrazy pochodzenia łacińskiego np. Maryja czy zakrystya. Praktykę nowoczesną zastosowano także w użyciu wielkich liter, które w XVIII w. stawiano odmiennie aniżeli dziś. Rozdziałowi poddano grupy wyrazowetypowe dlaówczesnej pisowninp. niemasz. Krótkienawiasy prostokątnezwielokropkiem i przypisem wewnątrz oznaczają nieczytelne części tekstu. W nawiasach takich odnotowano również numery stron rękopisu, na których znajdują się cytowane fragmenty oraz informacje pochodzące od wydawcy oddane kursywą. Przypisy bez nawiasów zawierają odsyłacze do wymienionych w tekście faktów, osób i innych objaśnień. Opuszczone fragmenty tekstu wizytacji oznaczone zostały dwoma kreskami --, zaś ich zawartość omówiono w przypisach. Pogrubione tytuły poszczególnych części tekstu nie pochodzą od wydawcy, lecz od autora protokołu.

Wszelkie odstępstwa od kształtu tekstu oryginalnego oraz zasad przyjętych przez K. Lepszego nawiązują do zastosowań określonych przez S. Litaka, który słusznie stwierdził, że „Instrukcja (Lepszego - D.Sz.) została opracowana wytacznie pod katem źródet proweniencji państwowej [...]. Nie uwzględnia ona specyfiki źródet kościelnych"34. Tak więc przytoczone w tekście tytulatury podano w brzmieniu oryginalnym. Podobnie nazwiska podano zgodnie z językiem źródła. Wythuszczone tytuły działów umieszczono na początku akapitów, a nie jak w oryginale $\mathrm{w}$ formie nagłówków. Poszczególne części tekstu oddzielone są jedynie światłem ${ }^{35}$. Ponadto nietypowe dla dzisiejszego czytelnika słownictwo wyjaśniono $\mathrm{w}$ przypisach, gdzie podano także informacje o zidentyfikowanych osobach, miejscach i wydarzeniach ${ }^{36}$.

${ }^{33} \mathrm{~K}$. Lepszy, Instrukcja wydawnicza dla źródet historycznych od XVI do połowy XIX wieku, Wrocław 1953, s. 6-27. Drobne uwagi co do zasad ustalonych przez Lepszego przekazał m.in. Marian Radwan (Wizytacje generalne parafii unickich w województwie kijowskim i bracławskim, s. 18). Dla starszych źródeł pisanych polecane są z kolei m.in.: Instrukcja wydawnicza dla średniowiecznych źródel historycznych, Kraków 1925, s. 17-18; A. Wolff, Projekt instrukcji wydawniczej dla pisanych źródet historycznych do połowy XVI wieku, ,, Studia Źródłoznawcze” (dalej: SŹ), 1 (1957), s. 155-181; Z. Budkowa, M. Friedbergowa, B. Kurbisówna, Instrukcja dla wydawnictwa roczników polskich, SŹ, 1 (1957), s. 182-184.

${ }^{34}$ Litak, Wstęp, w: Akta wizytacji generalnej diecezji inflanckiej i kurlandzkiej, s. XLIII.

${ }^{35}$ Zob. tamże, s. XLIII-XLVII.

${ }^{36}$ Por. A. Biedrzycka, Kościót katedralny w Kamieńcu Podolskim, ,Rocznik Biblioteki Naukowej PAU i PAN", R. XLVIII, s. 10 i nn. 


\section{MODLIBORZYCE MIASTO}

Stan fary i kościoła modliborzyckiego. [s. 556] -- ${ }^{37}$ Kościół w miasteczku Modliborzycach murowany i sklepiony cały, wysoki, wspaniały, nowo zewnątrz i wewnątrz wybielony ${ }^{38}$. Kaplic 8 krzyżowych $--^{39}$.

Kopuła białą blachą pobita. Wchodząc do kościoła są drzwi dębowe na zawiasach z zasuwą wewnątrz. Drugie od cmentarza na zawiasach z zasuwą. Drzwi na boku są dębowe na zawiasach z zamkiem i na kłódkę się zamykające.

Grobów jest 3. Niedawno reperowane, u których włazy żelazne.

$\left[\ldots{ }^{40}\right]$ w małym chórze są na obydwie strony. Posadzka kamienna.

$\mathrm{W}$ chórze wielkim podłoga $\mathrm{z}$ tarcic, także i w zakrystyi.

Ołtarz wielki, struktura drewniana, malowany i złocony, w nim jest obraz Wniebowzięcia N. M. Panny, wyżej Ś. Stanisława Biskupa i m. na portalu na mensie ${ }^{41}$ murowany.

Ołtarz 2gi po lewej stronie w wielkim chórze murowany i portalu. Struktura drewniana, malowana i złocona, w nim obraz, [s. 557] Ś. Antoniego, wyżej Ś. Heleny.

${ }^{37}$ Niejako tytułem wstępu wizytator podał dystans (w milach) jaki dzieli Modliborzyce od Lublina, Urzędowa, Kielc i Krakowa. Wyliczył sześć wsi parafialnych, ustalił odległości między nimi a kościołem modliborzyckim, zapewne przybliżony stan liczbowy wiernych w parafii (2300 osób) oraz odnotował liczbę udzielonych w poprzednim roku kalendarzowym (1780) w kościele parafialnym chrztów, ślubów i odbytych pogrzebów. Dzięki rejestrom pogłównego znana jest także minimalna liczba rodzin zamieszkujących tak miasto Modliborzyce, jak i całą parafię i jej poszczególne wsie już w 1674 r. (zob. AGAD, Archiwum Skarbu Koronnego, Oddział I, sygn. 4020, nr 162, k. 61). W 1682 r. liczbę parafian wizytator ustalał na 1200 (AKMKr., AV Cap. 66, s. 14). Z kolei w 1801 r. wizytator podał liczbę 3333 mieszkańców parafii, w tym 394 Żydów (por. BPAN-PAUKr., rkps. 2375, s. 329), natomiast w kwietniu 1821 r. samo miasto Modliborzyce zamieszkiwało 821 osób (AGAD, KRSW, sygn. 3194, s. 196), a w 1865 r. 1087 osób (tamże, sygn. 3817). Przeciętne roczne liczby chrztów udzielonych w kościele w Modliborzycach w latach 1671-1800 (za wyjątkiem lat 1691-1700) podał, na podstawie wiarygodnych zestawień kościelnych Zygmunt Sułowski, Dzieje zaludnienia obecnych powiatów kraśnickiego i janowskiego, w: Z dziejów powiatu kraśnickiego, Lublin 1963, s. 37, zaś stan ludności na tym terenie od 1325 do 1932 r. Leon Kuśmierczyk, Rozwój zaludnienia parafii Stupie-Modliborzyce, „Wieści Gminne”, 11 (2008) s. 27.

Obraz położenia geograficznego kościoła modliborzyckiego na tle sieci parafialnej w Polsce II połowy XVIII w. dał niedawno S. Litak, Atlas Kościoła łacińskiego w Rzeczypospolitej Obojga Narodów w XVIII wieku, Lublin 2006, mapa XXII, s. 139.

${ }^{38} \mathrm{~W} 1737$ r. wizytator stwierdził jeszcze zły kościoła, wymagającego remontu (AAL, A 101, brak paginacji).

${ }^{39}$ Dalej wizytator przekazał informacje o okolicznościach konsekracji kościoła w 1668 r. oraz o przywiezieniu do niego relikwii kilku świętych (m.in. św. Bazylego) przez oficjała lubelskiego Stanisława Rajmunda Jezierskiego w 1764 r.

${ }^{40}$ Miejsce nieczytelne.

${ }^{41}$ Łac. mensa itineraria - kamienna czworoboczna płyta, będąca ołtarzem przenośnym, nazywana także portatylem. Symbolizuje stół przy którym w wieczór wielkoczwartkowy Jezus spożywał ucztę z uczniami. Konsekrowana przez biskupa mensa, posiada wgłębienie na relikwie świętych oraz przedmioty liturgiczne. Może pełnić rolę tabernakulum (Mensa, w: Vyskupo Ignoto Jokübo Masalskio kauno dekanato vizitacija, s. 873). 


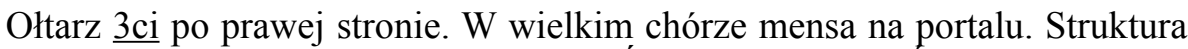
drewniana, malowana, postawna. Ma obraz Ś. Mikołaja wyżej S. Franciszka.

Kaplica bracka ${ }^{42}$. W niej ołtarz, mensa murowana i portal. Struktura drewniana, malowana, i złocona, ma obraz N. P. Różańcowej wyżej ŚŚŚ. Trójcy.

Kaplica 2ga w niej ołtarz. Murowana konsekrowana mensa, struktura drewniana, malowana i złocona, jest pod tytułem Ś. Jana Ewangelisty którego obraz w ołtarzu wyżej Ś. Anny ${ }^{43}$.

Zakrystya podłogę z tarcic mająca $\left[\ldots^{44}\right]$ i porządki $\left[\ldots{ }^{45}\right]$ na chowanie rzeczy kościelnych, i przyzwoite opatrzenie.

Chór murowany nie dawno reperowany $\mathrm{z}$ kościołem.

Dzwonnica murowana w roku 1775 z szczodrobliwej łaski ś. p. w. p. Kaspra Borawskiego podstarosty grodzkiego lubels.[kiego $]^{46}$ ma dzwonów 3. A 4ty mały za konających -- ${ }^{47}$.

${ }^{42} \mathrm{~W}$ innym miejscu wizytator zauważył, że kaplica ta stanowiła miejsce spotkań Bractwa Różańcowego (AAL, A 105, s. 569). Jak dotąd nie stało się ono przedmiotem szerszego zainteresowania badaczy. Podobne mu XVIII-wieczne bractwa, z nieodległych względem Modliborzyc parafii, opisali m.in. J. Flaga, Bractwa religijne w Archidiakonacie lubelskim $w$ drugiej połowie XVIII wie$k u$, „Wiadomości Diecezjalne Lubelskie”, XLVI (1972) nr 6, s. 137-143; S. Orzeł, Dominikanie w Janowie Lubelskim w latach 1660-1864, w: Janów Lubelski 1640-2000, red. Z. Baranowski, B. Nazaruk i J. Łukaszewicz, Janów Lubelski 2000, s. 271-272; M. Surdacki, Bractwa religijne w Urzędowie w XVI-XVIII wieku, „Kwartalnik Historii Kultury Materialnej”, 3-4 (2003) s. 355-386; Tenże, Edukacja i opieka spoteczna w Urzędowie XV-XVIII, Lublin 2004, s. 156-162; Tenże, Urzędów w XVII i XVIII wieku. Miasto-społeczeństwo-życie codzienne, Lublin 2007, s. 429-432.

${ }^{43}$ Wiadomo, że obraz św. Anny znajdował się w jednym z ołtarzy już w 1682 r. (AKMKr., AV Cap. 120; por. AKMKr., AV Cap. 66, s. 13), jednak trudno stwierdzić czy chodzi tu o to samo malowidło.

${ }^{44}$ Miejsce nieczytelne.

${ }^{45}$ Tak samo.

${ }^{46}$ Chodzi tu o Kaspra Antoniego Borawskiego vel Borowskiego, podstarościego lubelskiego, w latach 1777-1778 także łowczego urzędowskiego, zaś w latach 1778-1779 cześnika urzędowskiego. Zmarł on w 1779 r. (Urzędnicy województwa lubelskiego XVI-XVIII wieku. Spisy, opr. W. Kłaczewski i W. Urban, Kórnik 1991, nr 706 i 714, s. 94-95). Z parafią modliborzycką Borawski związany był od 1768 r. (AAL, Rep 60, A 105, s. 566). Ufundował wówczas aniwersarz o wartości 1000 zł. za swoją duszę po śmierci. Ponadto 20 stycznia 1779 r. przeznaczył 6000 zł. na reperację kościoła w Modliborzycach (ks. J. Bazylak, Zarys historii parafii Modliborzyce (cz. 1), „Janowskie korzenie", 6 (2006) s. 22).

${ }^{47} \mathrm{~W}$ tym miejscu wizytator podał informacje o wyglądzie i czasie odlania dwóch z czterech dzwonów. Oba wykonać miał ten sam ludwisarz. Największy wykonano na koszt plebana i innych, bliżej nie określonych osób., być może wiernych. Za drugi zapłacił miecznik orłowski niejaki Łaziński, prawdopodobnie spokrewniony z Kazimierzem Łazińskim, w 1722 r. posesorem zastawnym wsi Wolica należącej do parafii modliborzyckiej (por. Materiały źródłowe do dziejów Żydów w księgach grodzkich lubelskich z doby panowania Augusta II Sasa 1697-1733, opr. H. Gmiterek, Lublin 2001, nr 1527, s. 282). Oba dzwony poświęcił w 1776 r. oficjał okręgowy i sufragan lubelski oraz archidiakon sandomierski ks. Jan Kanty Lenczowski. W latach 1790-1792 był on proboszczem kościoła św. Ducha w nieodległym Urzędowie (M. Surdacki, Szpital świętego Ducha i św. Leonarda w Urzędowie w XV-XVIII wieku, „Kwartalnik Historyczny”, CXII (2004) nr 2, s. 27-28). Jeszcze w 1682 r. kościół modliborzycki posiadał tylko jeden dzwon (AKMKr, AV Cap. 12, s. 120). 
Kosnicy (sic!) na cmentarzu żadnej nie masz.

Cmentarz jest parkanem drewnianym opasany częścią reperowany.

Kaplica na starym cmentarzu gontami pobita pod tytułem Ś. Maryi Magdaleny, na Słupi -- ${ }^{48}$, na niej jest kopuła białą blachą pobita z dzwonkiem, jest oparkowana.-- ${ }^{49}$.

Jest kaplica w Wierzchowiskach opodal ode dworu, w której wszelka znajduje się przystojność. Indult ${ }^{50} \mathrm{z}$ Krakowa otrzymany a. d. 1777. 19. junij adquinquennsium.

Jest kaplica w Wolicy wchodząc do dworu na ganku ma indult otrzymany w Lublinie a. d. 1771. 13. augs. prorogowany ad decimium trium annorum post multom prorogationes a.d. 1779. 20. augs. in Gościeradow per r [evere]ndum Wybranowski $^{51}$ iudicem surrogatam. [s. 558]

Jest kaplica w Polichnie opodal od dworu oparkowany ma indult otrzymany

${ }^{48}$ Dalej kilka słów wizytatora o uroczystościach ku czci patronki tej kaplicy.

${ }^{49}$ Tu kilka słów o dziedzicach Modliborzyc - podstarościnie lubelskiej Teofili z Nahoreckich Borawskiej, Teresie z Nahoreckich i jej mężu Antonim Skarżyńskim, mieczniku łomżyńskim. Teofila i Teresa były córkami Anny Nahoreckiej i Samuela Nahoreckiego, starosty kolechickiego i posesora dóbr Modliborzyce w 1722 r. (Materiaty źródtowe do dziejów Żydów w księgach grodzkich lubelskich z doby panowania Augusta II Sasa 1697-1733, nr 1527, s. 282). Zapewne niebawem po 1781 r. przestali być oni właścicielami miasta, skoro w latach 1783-1784 jedynym właścicielem Modliborzyc był już Wojciech Wierciński, wojski większy drohicki od 1782 do 1793 r. (Urzędnicy podlascy XIV-XVIII wieku. Spisy, opr. E. Dubas-Urwanowicz, W. Jarmolik, M. Kulecki i J. Urbanowicz, Kórnik 1994, nr 734, s. 99), będący także właścicielem Dąbia, Słupia, Polichny i Wierzchowisk w parafii modliborzyckiej (,Regestr diecezjów” Franciszka Czaykowskiego czyli właściciele ziemscy $w$ Koronie w latach 1783-1784, do druku przyg. S. Górzyński, Warszawa 2006, s. 368-369 i 386, przyp. 1571). W kościele w Modliborzycach znajduje się obecnie murowane klasycystyczne epitafium Teresy z Nahoreckich (zm. 1801) i jej późniejszego męża Antoniego Dolińskiego (zm. 1811), ufundowane w 1827 r. przez ich syna Feliksa Dolińskiego (por. ks. J. Bazylak, Zarys historii parafii Modliborzyce (cz. 1), , Janowskie korzenie”, nr 6 (2006) s. 25). Dolińscy byli właścicielami dóbr modliborzyckich po Wiercińskich. Z. Góralski spostrzegł, iż w 1762 r. starosta kolechicki Antoni Nahorecki dotował szpital przykościelny w Modliborzycach (Góralski, Szpitale na Lubelszczyźnie, s. 86-87).

${ }^{50}$ Zezwolenie, łaska, dyspensa, akt kompetentnego przełożonego kościelnego zwalniającego od zachowania określonego obowiązku wyznaczonego przez prawo, wydany w formie reskryptu (E. Wilemska, Indult, w: Encyklopedia katolicka, t. VII, red. S. Wielgus, Lublin 1997, s. 146; Wizytacje generalne parafii unickich w województwie kijowskim i bracławskim, s. 904).

${ }^{51}$ Może tu chodzić o Stanisława Wybranowskiego, ówczesnego chorążego lubelskiego, zmarłego 3 kwietnia 1780 r. (Urzędnicy województwa lubelskiego, nr 29, s. 20). Zdaniem Teodora Żychlińskiego był to ówczesny właściciel wspomnianego w wizytacji Gościeradowa (Złota księga szlachty polskiej, opr. T. Żychliński, t. II, Poznań 1880, s. 348). Nie można jednak wykluczyć, że ten fragment tekstu odnosi się do ojca Stanisława Józefa, od 1779 r. starosty urzędowskiego lub nawet do ich kuzyna Rajmunda Wybranowskiego, dobroczyńcy kościoła farnego urzędowskiego (Surdacki, Urzędów w XVII i XVIII wieku, s. 237, 249). 
w Krakowie ${ }^{52}$, tandem cum prorogatione ad 3. annos per r[evere $]$ ndum Bodurkiewicz ${ }^{53}$ 15. aprilis 1766 Cracovia. [s. 559] --54.

Stan ekonomiczny i dochodowy kościoła farnego w Modliborzycach. Rezydencja drewniana na placu plebańskim na południe postawiona w roku 1748 . Izba jest w której 2 okna i alkierz ${ }^{55}$ w którym także 2 okna. $Z$ tego alkierza idąc, jest spiżarka, w izbie jest piec kaflany i kominek, drzwi do tej izby dębowe na zawiasach żelaznych z zamkiem. Na przeciwko tej rezydencji jest izba w której są 3 okna, i alkierz, ale przez cesarskich żołnierzy, którzy przez lat niemal 4 stali w tej rezydencji ${ }^{56}$, tak piec kaflany, jako i chlebowy porujnowany, a według ich upodobania postawiony ${ }^{57}$. Ta rezydencja gontami niedawno pobita. Przy tej rezy-

${ }^{52}$ Wszystkie wymienione tu kaplice prywatne otrzymały indulty na odprawianie mszy (por. BPAN-PAUKr., rkps. 2375, s. 331).

${ }^{53}$ Chodzi tu zapewne o Henryka Bodurkiewicza, ulubieńca biskupa krakowskiego Kajetana Sołtyka. W 1762 r. Bodurkiewicz został kanonikiem katedralnym krakowskim, zaś w 1764 r. otrzymał doktorat obojga praw na Uniwersytecie Krakowskim (H. Barycz, Bodurkiewicz Henryk (zm. 1796), kanonik katedralny krakowski, w: PSB, t. I, Kraków 1936, s. 180-181).

${ }^{54}$ Dalej, na stronach 559-565, wizytator przedstawił obowiązki dziesięcinne mieszkańców wsi parafialnych oraz inwentarz kilkudziesięciu przechowywanych w kościele przedmiotów i ubiorów liturgicznych oraz ksiąg tamtejszej biblioteki. Najstarsze były księgi metrykalne sięgające $1674 \mathrm{r}$., chociaż biblioteka posiadała rzekomo również dokument fundacyjny kościoła z 1629 r. Zdaniem Urszuli Bzdyry najstarsza księga metrykalna przechowywana obecnie w Archiwum Parafialnym w Modliborzycach obejmuje lata 1736-1798 (por. U. Bzdyra, Syn ziemi modliborzyckiej Wincenty Pieńkowski, „Wieści Gminne”, nr 14 (2009), s. 24), chociaż przeprowadzając przed trzema laty kwerendę odnotowałem obecność na plebani jako najstarszej księgi chrztów prowadzonej od 1751 r. Księgi starsze znajdowały się na parafii jeszcze w 1901 r. (por. Sułowski, Dzieje zaludnienia, w: Z dziejów powiatu kraśnickiego, s. 36, przyp. 8).

${ }^{55}$ Niewielki boczny pokój pełniący różne funkcje np. sypialni, często przylegający do większego pomieszczenia (B. Rykiel-Kempf, Alkierz, Jalkierz, Alkisz, w: Stownik języka polskiego XVII i 1. polowy XVIII wieku, t. I, z. 3, Kraków 2000, s. 88).

${ }^{56}$ Wizytator miał tu na myśli wydarzenia $z$ lat $1772-1776$. W efekcie I rozbioru Polski (1772) Modliborzyce znalazły się bowiem w granicach Austrii, jednak już po 4 latach, na mocy układu polsko-austriackiego z 30 czerwca 1776 r., wraz z kilkoma innymi miastami województwa lubelskiego oraz siedmioma parafiami dekanatu urzędowskiego, powróciły do granic Rzeczypospolitej (AGAD, zbiory kartograficzne, sygn. 514-6a, Ausschnitt Lublin 1776; B. Kumor, Dzieje diecezji krakowskiej, t. I, Kraków 1998, s. 152-153; H. Rożek, Powstanie Janowa Lubelskiego i jego rozwój w okresie staropolskim, w: Janów Lubelski 1640-2000, s. 24).

${ }^{57}$ Ówcześni Polacy, a szczególnie ci, którzy znaleźli się w granicach państwa austriackiego w wyniku I rozbioru, wyrażali się przeważnie bardzo negatywnie o Niemcach cesarskich. O armii austriackiej mawiano, iż jest pozbawiona patriotyzmu, płochliwa i uciekająca z pola walki oraz złożona ,z samych rozbójników i kontrabandzistów" (czyt. szerzej D. Rolnik, Portret szlachty czasów stanistawowskich, epoki kryzysu, odrodzenia, i upadku Rzeczypospolitej w pamiętnikach polskich, Katowice 2009, s. 377-385).

Wiadomości o kosztach ponoszonych przez miasto Modliborzyce z tytułu stacjonowania w nim oddziałów wojskowych przynosi nam partia składek z lat 1687-1739, pozostałych po nie zachowanej tzw. księdze dekretowej miasta, wzmiankowanej jeszcze w 1784 r. (zob. J. Łosowski, Kancelarie miast szlacheckich województwa lubelskiego, s. 100). Pobyty takie skutkowały niejednokrotnie także stratami materialnymi, jak w 1669 r., gdy zniszczeń dopuściła się chorągiew pancerna chorążego 
dencji jest kuchnia, przy niej komora, i druga komórka, ale cesarscy na stajenkę komorę obrócili. Pleban przeszły ${ }^{58}$ na tym placu wystawił spichlerz, z którego cesarscy rezydencję zrobili, kiedy w ścianach kazali okna porobić, który jest napsowany i skantowany potrzebuje reperacji. Na tymże placu dzisiejszy pleban kazał studnię wyrobić i opatrzyćs9.

Stodoła na tymże placu jest o dwu zapolach słomą pokryta. Stajnia przy stodole i wozownia. Resztę zaś placu tego do plebanii należącego pleban zasiewa.

$\mathrm{Na}$ dawnym placu w rogu cmentarza od miasteczka gdzie był przed tym szpital, jest pomieszkanie wystawione dla organisty ${ }^{60}$, w którym jest izba o dwu oknach ku cmentarzowi, a bardziej ku zakrystii, i komora. Drzwi na zawiasach żelaznych piec kamienny, i drugi chlebowy. Dachem pobita, i nie dawno ta mieszkalnia poprawiona. Na drugiej stronie jest plac należący do szpitala który się ciągnie przez troje sta[... $]^{61}$, ku stawowi i drodze do Dąbia bieżącej. Na tym placu jest wystawiony szpital w którym są 4 izby, w jednej izbie 2 okna, w drugiej i 3 ciej po jednym oknie, w 4tej są dwa okna. Dwie izby o jednym piecu, i komin mają wywiedziony. [s. 566] Resztę tego placu należącego do szpitala zasiewa mieszczanin, i daje trzecinę ubogim ${ }^{62}$. W tym szpitalu jest ubogich czworo $^{63}$.

Na Słupi Dłutowej dawno zwanej jest pomieszkanie dla plebana, dla wygody jego $^{64}$. Izba w której okien 3. Piec murowany z kominem. Podłoga z tarcic, przy

koronnego Hieronima Mikołaja Sieniawskiego (Materiaty źródłowe do dziejów Żydów w księgach grodzkich lubelskich z doby panowania Władysława IV i Jana Kazimierza Wazów 1633-1669, nr 1177, s. 196), lub w 1712 r., gdy miasto złupiły wojska moskiewskie, kozackie i kałmuckie (Materiały źródłowe do dziejów Żydów w księgach grodzkich lubelskich z doby panowania Augusta II Sasa 1697-1733, nr 941, s. 187).

${ }^{58}$ Chodzi tu o poprzedniego proboszcza ks. Andrzeja Byczyńskiego, zm. w 1775 r. (AAL, Rep 60, A 105, s. 566; por. Spis prepozytów i plebanów diecezji krakowskiej, s. 362).

${ }^{59}$ Chodzi tu o ówczesnego proboszcza ks. Macieja Kiślewicza, co wskazuje, że studnię przy kościele wydrążono między 1775 a $1781 \mathrm{r}$.

${ }^{60}$ Z. Góralski uważał, że miało to miejsce jeszcze w końcu XVII w. (Góralski, Szpitale na Lubelszczyźnie, s. 86).

${ }^{61}$ Miejsce nieczytelne.

${ }^{62}$ Dziwi brak w wizytacji informacji o szczegółach funkcjonowania szkoły parafialnej, która istniała w Modliborzycach już co najmniej od 1682 r., zaś poprzednio (przynajmniej od początku XVII w.) działała przy kościele w Słupiu (czyt. szerzej AKMKr, AV Cap. 12, s. 120; S. Kot., Szkolnictwo parafialne w Małopolsce XVI-XVIII wieku, Lwów 1912, s. 230-231). Wizytator odnotował jednak obecność przy kościele dyrektora tej szkoły (por. BPAN-PAUKr., rkps. 2375, s. 330).

${ }^{63} \mathrm{O}$ szpitalu tym pisał Z. Góralski. W jego fundatorze widział ks. Stanisława Tutkowskiego, a fundację ogólnie datował na II poł. XVII w. (Góralski, Szpitale na Lubelszczyźnie, s. 86). Tutkowski był pierwszym proboszczem w Modliborzycach - od 1654 r. (AKMKr, AV Cap. 12, s. 121 - tam więcej o jego karierze duchownej). Nie mógł być fundatorem szpitala, gdyż skądinąd wiemy, że ufundował go S. Wieteski w 1654 r. (APK/OS, sygn. 949/189, nr 4). Już w 1657 r. szpital był dotowany przez niejakiego Szwaykowskiego, kolejna dotacja nastąpiła zaś prawdopodobnie dopiero w 1685 r. (AKMKr., AV Cap. 66, s. 15). W oparciu o księgi miejskie modliborzyckie Góralski wyliczył 7 przypadków dotacji tego szpitala z lat 1690-1762 (Góralski, Szpitale na Lubelszczyźnie, s. 86-87).

${ }^{64}$ Rezydencja proboszcza znajdowała się w Słupi jeszcze w okresie istnienia tam kościoła parafialnego. Przeniesienie parafii do Modliborzyc w 1654 r. niczego w tym zakresie nie zmieniło 
tej izbie jest komora, na przeciwko jest izba dla czeladzi okien w niej 3. Piec murowany, i chlebowy, przy tej jest komora na schowanie, komin wywiedziony i wylepiony, te budynki dachem są pobite. Stodoła jedna o dwóch zapolach wyreparowana i poszyta. Wozownie dwie a stajnia jedna. Chlew dla wołów. Chlewów 4 dla bydła. Podwórze oparkowane. $\left[\ldots{ }^{65}\right]$ jeden. [s. 567] ---66.

Stan ekonomiczny i dochodowy prebendy różańcowej. Dom mieszkalny prebendarza $^{67}$ jest przy kościele ${ }^{68}$ na placu wzwyż wyrażonym ${ }^{69}$, w którym jest izba $z$ alkierzem w tej okien 3. W alkierzu okien 2. Piec kaflany, i kominek. Drzwi, tak do izby idąc na zawiasach żelaznych, jako i do alkierza z zamkami.

Na przeciwko teraz nowo wystawił x. prebendarz izbę dla czeladzi ${ }^{70}, w$ której okien 2. Piec murowany i 2 gi chlebowy. Dach nowy. Drzwi do izby na zawiasach i do komory. Komin murowany na dach wywiedziony. Studnia. Stodoła dawnego krycia która o 2 zapolach. Przy tej stodole jest mała stodółka o jednym zapolu. Spichlerz stary dobrze przykryty, przy którym wozownia. Dalej dla bydła chlewów 2 i dla niebogatego chlewek 1. Stajenka dla koni. [s. 570]--71.

(por. AKMKr., AV Cap. 66, s. 14; BPAN-PAUKr., rkps. 2375, s. 330).

${ }^{65}$ Miejsce nieczytelne.

${ }^{66} \mathrm{Na}$ dalszych stronach (s. 568-570) wizytator przedstawił inwentarz zwierząt będących własnością parafii, liczbę zboża zebranego podczas żniw na terenie parafii, wydatki kościoła na potrzeby proboszcza, organisty czy na zakup wina, stan liczebny duchowieństwa, wyposażenie kaplicy Bractwa Różańcowego oraz wylicza przechowywane w kościele dokumenty z lat 1654-1751 dotyczące prebendy różańcowej.

${ }^{67}$ Duchowny obdarzony prebendą, czyli uposażeniem ziemskim lub dochodami, rodzaj beneficjum, niekiedy związany z funkcją kanonika (J. Dokurno, Prebenda, prebendarz, w: Stownik polszczyzny XVI wieku, t. XXX, Warszawa 2002, s. 243).

${ }^{68}$ Prebendarz mieszkał przy kościele już od czasu jego fundacji (zob. Chlebowski, Modliborzyce, w: Stownik geograficzny, t. VI, s. 566).

${ }^{69}$ Chodzi tu prawdopodobnie o budynek znajdujący się poza murami kościoła, ale w jego bezpośrednim sąsiedztwie. Tymczasem w 1737 r. prebendarz mieszkał jeszcze w samym kościele, w dobudówce kryjącej pierwotną fasadę kościoła, a w przyziemiu kruchtę z pomieszczeniami po bokach, wzniesionej w 4. ćwierci XVII w. w przedłużeniu nawy od zachodu (zob. Katalog zabytków sztuki $w$ Polsce, t. VIII, z. 7, s. 9).

${ }^{70} \mathrm{Z}$ tekstu wizytacji nie wynika jednoznacznie gdzie mieszkali inni duchowni. Brak tu także informacji o domu wikarego o którego istnieniu wiemy z protokołu wizytacji parafii z $1689 \mathrm{r}$. (AKMKr., AV Cap. 66, s. 13).

${ }^{71}$ Tekst wizytacji kończy umieszczony na stronach 570-571 tzw. inwentarz prebendarski oraz dekret reformacyjny ze stron 571-572. Ten ostatni nakazywał plebanowi do końca 1782 r. wyremontowanie okien w kościele, ponowne oparkowanie cmentarza i wystawienie na nim kostnicy, do końca 1783 r. przygotowanie materiału na nowy budynek plebański, który miał pochodzić z rozebrania kaplicy św. Marii Magdaleny na Słupiu, zaś do końca 1784 na miejscu spichlerza miała stanąć nowa plebania z kominem. Gdy ks. Dunin-Kozicki wizytował w 1781 r. kościół św. Ducha w Urzędowie również nakazał, aby budulec na nowy przytułek przykościelny pochodził ze starych, zniszczonych budynków kościelnych - kościółków św. Elżbiety i św. Otylli (zob. M. Surdacki, Szpital świętego Ducha i św. Leonarda w Urzędowie, „Kwartalnik Historyczny”, CXII, nr 2, s. 11). Wizytacje odbywane po 1781 r. nie wspominają już o kaplicy słupskiej (por. BPAN-PAUKr., rkps. 2375, s. 331). Jej ostatecznej rozbiórki dokonano jednak dopiero niedługo przed 1885 r. (zob. Chlebowski, Modliborzyce, w: Stownik geograficzny, t. VI, s. 566). 


\section{DER ZUSTAND DIE KIRCHGEBÄUDEN AN DER PFARRGEMEINDE UNTER DEM ZURUFEN HEILIGEN STANISLAU DES BISCHOFS IN MODLIBORZYCE BASIEREND AUF DER VISITATION DES PFARRERS ANTONI FRANCISZEK DUNIN - KOZICKI IN 1781 JAHR}

\section{Zusammenfassung}

Die Visitationdossier der polnisches Pfarrgemeinde aus XVIII Jahrhunderts bilden ausgezeichnete Quelle in die Erkenntnis der Geschichten, einzeln Pfarrkirchen, in desto ihr materiell Zustand. So ist auch in dem Zufall der Visitation der Pfarrgemeinde unter dem Zurufen Heiligen Stanislau des Bischofs in Modliborzyce in 1781 Jahr. Diese Pfarrgemeinde kam zweifellos in XVII Jahrhundert auf. Man urteilte bis jetzt, dass es in 1664 Jahr folgte. Meiner Meinung nach, in der Wirklichkeit, folgte das schon in $1654 \mathrm{Jahr}$, oder sogar früher. In dem Gegensatz von alte Visitation dieser Pfarrgemeinde, durchführte wahrscheinlich von $1682 \mathrm{Jahr}$, die aus $1781 \mathrm{Jahr}$ informiert uns sehr genau über die $\mathrm{Zu}-$ stand ihr Bebauung. Wir erkundigen uns aus ihnen über dem Aussehen der Kirche, der Pfarrschule, des Pfarramts ob der Friedhof.

In dieser Arbeit publiziere ich gewähltes Fragmente der Visitation der Pfarrgemeinde in Modliborzyce aus $1781 \mathrm{Jahr}$, der die eben Aspekte ihr Funktionieren durchblitzen. Das Original der Visitation stammt aus dem Erzbistumarchiv in Lublin.

Auf Bedürfnis gegenwärtiger Veröffentlichung der Text der Visitation wird einverständlich mit Verlaganweisung von Herren K. Lepszy, M. Radwan und S. Litak bearbeitetet. Die Zugabe zu ihm ist altpolnisch und lateinisch Wörterbuch der Fristen anwenden in dem Text der Visitation. 